УДК 338.439-043.98

Лялюк Алла, кандидат економічних наук, доцент, Східноєвропейського національного університету імені Лесі Українки, кафедра економіки, безпеки та інноваційної діяльності підприємства м. Луцьк ORCID ID 0000-0002-4889-0511 e-mail: allalyalyuk@gmail.com

https://doi.org/10.29038/2411-4014-2020-01-108-116

\title{
ПРОБЛЕМИ ФАЛЬСИФІКАЦЇ̈ ХАРЧОВИХ ПРОДУКТІВ ТА ШЛЯХИ ЇЇ ПОДОЛАННЯ
}

У статті досліджено методи і засоби фальсифікації харчових продуктів, проаналізовано зарубіжний та вітчизняний досвід боротьби із зазначеним явищем. Систематизовано підхід до групування фальсифікованої продукції за їі окремими групами: асортиментною, якісною, інформаційною та кількісною. Окреслені шляхи, які зможуть унеможливити фальсифікацію харчових продуктів на вітчизняному споживчому ринку. Зроблено висновок, що боротьба з фальсифікацією харчових товарів, повинна здійснюватись насамперед у таких нарямах як розробка нових та удосконалення існуючих методів експертизи, створення координаційного центру для збору, аналізу та публікації аналітичних результатів з якості харчових продуктів спільної участі України 3 Міжнародними організаціями у розробці досконалих пристроїв за допомогою яких можна буде швидко та легко виявити фальсифіковані продукти/

Ключові слова: харчові продукти, фальсифікація, асортиментна фальсифікація, якісна фальсифікація., фальсифіковані продукти.

Лялюк Алла

кандидат экономических наук, доцент, Восточноевропейский национальный университет имени Леси Українки, кафедра экономики, безопасности и инновационной деятельности предприятия, г. Луцк

\section{ПРОБЛЕМЫ ФАЛЬСИФИКАЦИИ ПИЩЕВІХ ПРОДУКТОВ И ПУТИ ИХ ПРЕОДОЛЕНИЯ}

В статье исследованы методы и средства фальсификации пищевых продуктов, проанализирован зарубежный и отечественный опыт борьбы с указанным явлением. Систематизированы подход к группировке фальсифицированной продукции по отдельным группам: ассортиментной, качественной, информационной и количественной. Указанные пути, которые смогут предотвратить фальсификаций пищевых продуктов на отечественном потребительском рынке. Сделан вывод, что борьба с фальсификацией пищевых продуктов, должна осуществляться прежде всего в таких направлених как разработка новых и усовершенствование существующих методов экспертизы, создание координационного центра для сбора, анализа и публикации аналитических результатов по качеству пищевых продуктов совместного участия Украины Международным организациями в разработке совершенных устройств с помощью которых можно будет быстро и легко выявить фальсифицированные продукты/

Ключевые слова: пищевые продукты, фальсификация, ассортиментная фальсификация, качественная фальсификация, фальсифицированные продукты.

Lialiuk Alla

Associate Professor, Economics and Security of Enterprise Department, Lesya Ukrainka East European National University, Associate Professor, Ph.D. in Economics, Lutsk, 


\section{PROBLEMS OF FALSIFICATION OF FOOD PRODUCTS AND WAYS OF ITS ADDRESS}

The transition to a market economy, the privatization of manufacturing and the sale of goods in Ukraine have led to a rapid increase in the number of independent enterprises, which has resulted in a weakening of state control and supervision over the quality and safety of products. The problem of quality has become acute social in nature. Because of this, a great deal of material and moral damage is caused, and millions of Ukrainians are at risk of health and life. The article investigates methods and means of falsification of foodstuffs, analyzes the foreign and domestic experience of combating this phenomenon. Also outlined are ways that can prevent food counterfeiting in the domestic consumer market.

The factors that lead to such a high level of fraud in the country are: lack of harmonized governance, imperfection of the legal framework; economic problems; weakening of state control and observation and lack of overall coordinating control bodies; lack of certification effectiveness; there is no strict responsibility of sellers for selling counterfeit products. The article gives specific examples of assortment of information and qualitative falsification of food products.

Today, the problem of food expertise has already gone beyond the interests of individual laboratories, scientific institutions and even states. In Ukraine, requirements for the development and implementation of food safety management systems are set by the relevant Laws, conditions are created for competition between private and public laboratories and the cost of relevant research is reduced. However, despite significant achievements in the field of counterfeiting and improving the quality and safety of products in Ukraine, which in the world as a whole face new problems: the scale of use of food additives is increasing every year, one of the modern directions of biotechnology creation of transgenic food products is intensively developing.

Therefore, the fight against food fraud should be undertaken in the following ways: development of new and improvement of existing methods of examination, creation of a coordination center for the collection, analysis and publication of analytical results obtained by individual centers and laboratories for the quality of food and raw materials; joint participation of Ukraine with the International organizations in the development of more sophisticated counterfeit detection devices; - adaptation of Ukrainian legislation to the requirements of EU legislation in the field of food quality regulation; development of methodology for evaluation of technical documentation regarding the ability of new equipment to produce quality and safe products; creating conditions for competition between private and public laboratories and reducing the cost of relevant research; mandatory inclusion of food producers in the Only Original system.

Key words: food products, falsification, assortment falsification, quality falsification., falsified products.

Постановка наукової проблеми та її значення Перехід до ринкової економіки, приватизація в галузі виробництва та реалізація товарів в Україні призвели до стрімкого зростання кількості самостійних підприємств, наслідком чого стало послаблення державного контролю і нагляду за якістю та безпекою продукції, в т.ч. і тієї, яка імпортується та реалізується на власному споживчому ринку. Зросла можливість виготовлення і поступлення у роздріб продукції, яка не відповідає вимогам, установленим національними та міжнародними стандартами. Проблема якості набула гострого соціального характеру. Україна перетворилася на місце, що займається продажем фальсифікованої продукції, недобросвісної вітчизняними та іноземними виробниками. Із-за цього наноситься величезний матеріальний і моральний збиток, піддається небезпеці здоров'я і життя мільйонів українців.

Аналіз досліджень цісї проблеми. Питання управління якістю продукції, і зокрема. Харчових продуктів підіймалось у працях таких вітчизняних та зарубіжних науковців як Ісікава Каору, Бондаренко Г. Г, Глєбова М. В., Сіроклин В. П., Чернобай Н. В., Смоляр В. І.,. Капінос Г. І., Грабовська I. В. Харрінгтон Джеймс та ін. $[1,10,11,14,15,17]$. Проте проблема недопущення проникнення на ринок фальсифікованої продукції на сьогодні лише загострюється, що вимагає

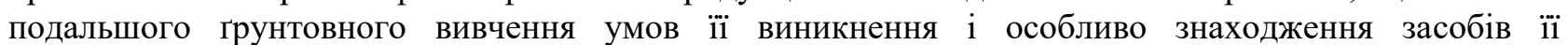
недопущення.

Мета і завдання статті. Дослідити методи i засоби фальсифікації харчових продуктів, проаналізувати зарубіжний та вітчизняний досвід боротьби із зазначеним явищем. Також окреслити шляхи, які зможуть унеможливити фальсифікацю харчових продуктів на вітчизняному споживчому ринку. 
Виклад основного матеріалу Слово фальсифікація походить від латинського «falcifiko», що означає «підробка». Фальсифікація - це дії, спрямовані на зниження якості, погіршення споживчих властивостей або зменшення кількості товару. При цьому зберігаються найбільш характерні, але несуттєві ознаки, що допомагає обдурити споживача [18].

Фальсифікація продовольчих товарів - це надання їм окремих типових характеристик при загальному погіршенні найбільш значимих властивостей харчової цінності, у тому числі безпечності. Тобто, фальсифікована продукція дуже схожа на справжню, майже так само пахне і смакує, має таку ж або схожу консистенцію, але при цьому не має повноцінних білків, жирів та вітамінів. Фальсифікат - це харчова продукція та продовольча сировина, у якій склад, властивості та характеристики спеціально замінені на гірші $[16,18]$.

Початок XXI століття став періодом масової фальсифікації харчових продуктів. За даними громадської організації «Всеукраїнська асоціація захисту прав споживачів» в Україні близько 80 \% харчової продукції фальсифіковано за одним або кількома показниками, за кількістю підробок $\mathrm{i}$ порушенню норм лідирує молочна продукція. плавлені сири, згущене молоко, сметана, кефір і навіть дитяче харчування. Потім ідуть соки, кондитерські вироби, крупи, вино та коньяк. Так, із 40-50 зразків вершкового масла, яке було відібрано для експертизи, приблизно $70 \%$ виявляється фальсифікатом. Також є випадки, коли молочний жир повністю замінюють рослинними чи тваринними жирами, походження яких навіть неможна визначити [4].

Варто погодитись 3 думкою заступника голови правління громадського об’єднання «Союз споживачів України» О. Цильвика про те, що безкарність виробників, призводить до того, що харчові продукти не лише стають гіршими за якістю, але і несуть реальну загрозу здоров'ю людей :«нам везуть прострочені імпортні продукти, щоб, перебивши маркування, продати в Україні задешево. Це, в свою чергу, породило нову хвилю виробництва і підробки іноземних брендів..» [4].

Чинниками, які обумовлюють такий високий рівень фальсифікації в країні є:

- відсутність гармонізованого управління;

- недосконалість нормативно-правової бази;

- економічні проблеми;

- ослаблення державного контролю і спостереження і відсутності в цілому координаційних контрольних органів;

- недостатня ефективність сертифікації;

- відсутня жорстка відповідальність продавців за реалізацію фальсифікованої продукції.

У науковій літературі розрізняють 5 видів фальсифікації: асортиментну, якісну, кількісну, кошторисну та інформаційну.

Асортиментна, або видова, фальсифікація - це повна або часткова заміна продукту його замінником, зі збереженням схожості однієї або кількох ознак $[1,14,15,18]$ (табл.1).

Приклади асортиментної фальсифікації продукції

\begin{tabular}{|c|c|}
\hline Вид харчової продукції & Опис фальсифікату \\
\hline борошно & заміна вищого сорту борошна на нижчий (у хлібі або макаронних виробах), \\
\hline йогурт & заміна одного виду плодів на інший (персик на яблуко у йогурті), \\
\hline шоколад і цукерки & $\begin{array}{l}\text { шоколадну глазур можуть вводити замість какао-масла (дорогий компонент) Щоб } \\
\text { збільшити масу глазурі - додають надто багато води та цукру. } \\
\text { У справжній глазурі, що } є \text { жировим середовищем, вода не розчиняється. Тому } \\
\text { фальсифікатори передбачливо вводять спочатку поверхнево-активні речовини - } \\
\text { лецитин, фосфатидні та інші концентрати. І завдяки цьому збільшують кількість води з } \\
\text { 1\% до 6-9\%. }\end{array}$ \\
\hline кисломолочний сир & $\begin{array}{l}\text { заміщують не тільки молочний жир, а й білок рослинним білком (соєвим) та } \\
\text { фіброволокнами. } \\
\text { Недобросовісні виробники сьогодні } 32 \text { тонн молока можуть видати тонну } \\
\text { «кисломолочного сиру», хоча традиційно (класика технології!) для цього потрібно } 8 \\
\text { тонн молока» }\end{array}$ \\
\hline $\begin{array}{l}\text { дорогі тверді сири а } \\
\text { гакож сир «Моцарелла» }\end{array}$ & молочний жир, недобросовісні виробники замінюють дешевшим, рослинним. \\
\hline
\end{tabular}

Джерело : [9, 13] 
Наприклад, заміна вищого сорту борошна на нижчий (у хлібі або макаронних виробах), шоколадну глазур можуть вводити замість какао-масла (дорогий компонент). Щоб збільшити масу глазурі - додають надто багато води та цукру у кисломолочному сирі заміщують не тільки молочний жир, а й білок рослинним білком (соєвим) та фіброволокнами і т.п. Підробку можна виявити за кольором, виглядом, смаком. Але точний результат може дати лише обладнана лабораторія.

Якісна фальсифікація - це підробка товарів за допомогою харчових та нехарчових добавок для покращення органолептичних властивостей. Інші споживчі властивості при цьому можуть бути втрачені $[14,18]$. Різновидом якісної фальсифікації є часткова або повна заміна натурального продукту на відходи. Наприклад, у ковбасних виробах можлива заміна частини м'яса на більш дешевий шпиг і з'єднувальну тканину, додавання рослинних компонентів (соя або кукурудза Застосування антибіотиків для продовження терміну зберігання продуктів. Понад 60 \% «згущенки» в Україні містять хімічні добавки, Підміняється жир молочного походження немолочним. Вони замінюють цукор, додають або сахарин, або аспартам додають діоксид титану та ін.

Таблиия 2

\section{Засоби якісної фальсифікації харчових продуктів}

\begin{tabular}{|c|c|}
\hline $\begin{array}{l}\text { Вид харчової } \\
\text { продукції }\end{array}$ & Опис фальсифікату \\
\hline $\begin{array}{l}\text { хлібобулочні } \\
\text { вироби }\end{array}$ & $\begin{array}{l}\text { використання відбілювачів, розрихлювачів замість дріжджів. недостатня кількість масла, яєць, } \\
\text { цукру. }\end{array}$ \\
\hline цукор & можуть додавати борошна, манної круги, солі, а то й будівельного гіпсу. \\
\hline морозива. & $\begin{array}{l}\text { замість молочних додають рослинні жири. Якщо на етикетці написано «вершки сухі рослинні, } \\
\text { соєвий білок, ароматизатори, емульгатори, загущувачі...», то такий продукт важко назвати } \\
\text { морозивом. }\end{array}$ \\
\hline ковбасні вироби & $\begin{array}{l}\text { можлива заміна частини м’яса на більш дешевий шпиг і з'єднувальну тканину, додавання } \\
\text { рослинних компонентів (соя або кукурудза }\end{array}$ \\
\hline чай & $\begin{array}{l}\text { це підмішування низькоякісних компонентів (волокон або черешків), продаж старого } \\
\text { низькоякісного продукту }\end{array}$ \\
\hline фрукти. цитрусові & $\begin{array}{l}\text { застосування антибіотків Якщо яблуко не псується цілий рік у звичайному холодильнику - воно } \\
\text { обов’язково пройшло якусь обробку: антибіотики - всередину, захисний шар з парафіну або } \\
\text { воску - на поверхню. У цитрусових шкідливі речовини частково видаляються разом зі шкіркою. } \\
\text { У яблуках або грушах - ні. Тому фрукти треба обов’язково мити щіточкою, і бажано у мильній } \\
\text { воді. А ще краще - зняти шкірку, особливо якщо фрукти купуються для дитини. }\end{array}$ \\
\hline згущене молоко & $\begin{array}{l}\text { часто додають прострочений цукор. Понад } 60 \text { \% «згущенки» в Україні містять хімічні добавки, } \\
\text { Підміняється жир молочного походження немолочним. Вони замінюють цукор, додають або } \\
\text { сахарин, або аспартам додають діоксид титану сахарин, або аспартам дітям до п’яти років це } \\
\text { взагалі не дозволено. }\end{array}$ \\
\hline майонез & $\begin{array}{l}\text { не докладають яєць. Якщо на упаковці пише майонезний соус,то «- він може бути низької } \\
\text { жирності, може бути взагалі без яєць. При виборі майонезу фахівці радять звертати увагу } \\
\text { на склад: на першому місці має бути рослинна олія, потім яйця і гірчиця, далі - оцет і лимонна } \\
\text { кислота. Останній інгредієнт - натуральні спеції }\end{array}$ \\
\hline вершкове масло & $\begin{array}{l}\text { замінити в ньому тваринні жири рослинними - пальмовим, кокосовим» пальмову олію, імпорт } \\
\text { цього продукту постійно зростає. Постійне вживання такого масла негативно позначається на } \\
\text { серцево-судинній системі, провокує діабет і навіть онкологію.Тому при виборі вершкового } \\
\text { масла рекомендують, насамперед, орієнтуватися на ціну. Вартість пачки справжнього масла } \\
\text { не може бути нижче } 40 \text { гривень }\end{array}$ \\
\hline $\begin{array}{l}\text { сосиски і ковбаси } \\
\text { вищого сорту }\end{array}$ & $\begin{array}{l}\text { додають так зване «м’ясо механічної обвалки» - суміш фаршу, подрібнених кісток, } \\
\text { субпродуктів Стандарт для цих виробів вимагає використовувати тільки натуральне м’ясо. }\end{array}$ \\
\hline $\begin{array}{l}\text { борошно та } \\
\text { крохмаль } \\
\end{array}$ & додавання крейди, гіпсу, вапна, золи \\
\hline $\begin{array}{l}\text { вершкове масло в } \\
\text { тортах та тістечках }\end{array}$ & заміна вершкового масла на маргарин забороняється законодавством \\
\hline молоко & додавання крейди і соди \\
\hline рідкі продукти & використовують воду \\
\hline соки, сиропи і напоі & доповнюютьсинтетичними барвниками або ароматизаторами. \\
\hline кофейні напої & заміна кавових зерен на зернові або цикорій \\
\hline
\end{tabular}


У цитрусових шкідливі речовини частково видаляються разом зі шкіркою. У яблуках або грушах - ні. Тому фрукти треба обов'язково мити щіточкою, і бажано у мильній воді. А ще краще - зняти шкірку, особливо якщо фрукти купуються для дитини.

Кількісна фальсифікація - це обман покупця за рахунок відхилення маси товару. Кількісна фальсифікація спричиняе обман споживачів шляхом значних відхилень параметрів харчового продукту (маси, об'єму, довжини) від допустимих нормативів [11, 18]. В практичній діяльності цей вид фальсифікації експерти називають недоваженням або недомірюванням. Так, в Україні «рекордсменами» $з$ обважування є кавуни.

Якщо інформація для покупця неточна або викривлена - ми маємо справу з інформаційною фальсифікацією [18] (табл.3).

Таблиия 3

Приклади використання інформаційної фальсифікації харчових прдуктів

\begin{tabular}{|l|l|}
\hline \multicolumn{1}{|c|}{ Вид харчової продукції } & \multicolumn{1}{|c|}{ Опис фальсифікату } \\
\hline $\begin{array}{l}\text { хлібобулочні або кондитерські } \\
\text { вироби }\end{array}$ & неправильно вказаний сорт борошна \\
\hline майже усі продукти харчування & $\begin{array}{l}\text { приваблива упаковка, що імітує продукт високої якості, тоді як } \\
\text { товар всередині далеко не вищого гатунку }\end{array}$ \\
\hline продукти харчування, & супровідні документи, що засвідчують якість. \\
\hline прострочені імпортні п & перебивши маркування, продають в Україні задешево \\
\hline
\end{tabular}

Джерело : $[9,12,13,19]$

Наприклад, приваблива упаковка, що імітує продукт високої якості, тоді як товар всередині далеко не вищого гатунку. Фальсифікації піддаються не лише маркування та упаковка, а і супровідні документи, що засвідчують якість. Складність ідентифікації полягає в тому, що в більшості випадків відсутні або не дуже надійні її критерії. Так, майже неможливо встановити ідентичність пшеничного борошна вищого гатунку, виготовленого одним хлібозаводом, але різними змінами та (або) виготовленого із борошна, одержаного від різних постачальників. За рубежем роблять спроби вносити у маркування харчових продуктів певну інформацію про їх приналежність до конкретної товарної партії. В Україні маркування, яке ідентифікує конкретну товарну партію, використовується лише для продукції консервної промисловості (консерви, пресерви). Очевидно, аналогічні способи партіонної ідентифікації доцільно було б розробити й для інших видів харчових продуктів.

Вартісна фальсифікація - це обдурювання покупця шляхом продажу низькоякісних товарів за ціною високоякісних або ж менші коштують як більші. Цей вид фальсифікації найбільш розповсюджений, бо може бути об'єднаний з усіма іншими.

Проблема фальсифікації харчових продуктів уперше постала ще понад три століття тому в Західній Європі, однак протягом XIX початку XX ст., зокрема у Німеччині, були виконані суттєві дослідження щодо викриття фальсифікації харчових продуктів (розроблена низка фізико-хімічних методів, сконструйовані необхідні прилади). Результати цих досліджень були запозичені i удосконалені російськими і радянськими науковцями та стали підгрунтям для створення основ продовольчої експертизи в Радянському Союзі. На сьогодні відбулось суттєве збільшення чутливості методів дослідження, що призвело до виявлення в харчових продуктах слідів забруднень, про які до цього часу навіть не підозрювали. Але розвиток науки привів до висновку, що абсолютно безпечних продуктів не існує, оскільки практично не існує жодного їхнього компонента, який не був би безпечним для тієї чи іншої категорії населення. Такий підхід дозволив сформулювати поняття ризику і його оцінку, що зумовило необхідність розробки допустимих рівнів шкідливих речовин в харчових продуктах, які є основою гарантування їхньої якості і безпеки. Заслуговує на увагу твердження Смоляр В. І. про те, що виходячи з вищевикладеного доцільно, щоб нормативнотехнічна документація систематично уточнювалась згідно 3 результатами сучасних наукових досліджень [15].

На сьогодні проблема харчової експертизи вже вийшла за рамки інтересів окремих лабораторій, наукових установ і навіть держав. Тепер вона знаходиться в центрі уваги міжнародних організацій: ВOОЗ, ФАО, ЮНЕП, ISO та ін. [15].. Міжнародними стандартами з якості є стандарти ISO серії 9000 і 10 000. В європейських країнах, що входять до складу Європейського союзу, національні стандарти 
з систем якості створюють або безпосередньо на базі стандартів ISO серії 9000, або посилаються на стандарти EN серії 29000[1, 11, 15 ].

В Україні вимоги щодо розробки та впровадження систем управління безпечністю харчової продукції встановлюють Закони України «Про якість та безпеку харчових продуктів і продовольчої сировини» [ 5]. та «Про захист прав споживачів»[6]. Зокрема, дотримання якості та безпеки за принципами НАССР задекларовані ДСТУ 4161-2003 «Система управління безпечністю харчових продуктів. Вимоги» та ДСТУ ISO 22000:2007 «Системи управління безпечністю харчових продуктів. Вимоги до будь-яких організацій харчового ланцюга». На підставі пункту 2 частини 2 ст. 20 Закону України «Про основні принципи та вимоги до безпечності та якості харчових продуктів» [7], особи, які займаються виробництвом або введенням в обіг харчових продуктів, повинні застосовувати системи НАССР та/або інші системи забезпечення безпечності та якості під час виробництва та обігу харчових продуктів [7]. Питаннями контролю якості та безпеки харчових продуктів займається Державний комітет стандартизації, метрології та сертифікації (Держстандарт) та Міністерство охорони здоров'я. Перевіряти операторів ринку на відповідність їх діяльності законодавству про харчові продукти, корми, здоров'я та благополуччя тварин має право Держпродспоживслужба. Процедури такого контролю визначено Законом «Про державний контроль за дотриманням законодавства про харчові продукти, корми, побічні продукти тваринного походження, здоров'я та благополуччя тварин»[8]

Важливим елементом європейської моделі забезпечення безпечності харчових продуктів $\epsilon$ створеня центрів та лабораторій якості харчових продуктів та продовольчої сировини. На початку 2019 р. держава відмовляється від жорсткої монополії у сфері державного контролю та делегує окремі повноваження суб'єктам приватного права. Таким чином, створено умови для появи конкуренції між приватними та державними лабораторіями та зниження вартості відповідних досліджень. У підсумку це дозволить оптимізувати мережу державних лабораторій та заощадити кошти платників податків, які витрачаються на систему контролю безпечності харчових продуктів. Для мінімізації ризиків фальсифікації досліджень урядом одночасно затверджено критерії, яким мають відповідати уповноважені лабораторії а також порядок перевірки державою діяльності уповноважених лабораторій [].

Зарубіжний досвід оцінки якості продуктів свідчить, про те, що насамперед потрібно звільнитися від елемента суб'єктивності в оцінці якості продукції. 3 цією метою розроблені біосенсори для аналізу вмісту етанолу в харчових продуктах, автоматичний прилад із напівпровідниковими датчиками для оцінки консервованих продуктів, біосенсор для визначення вмісту глюкози в харчових продуктах. швидке визначення вмісту цукрів в цілих, непошкоджених фруктах на базі глибинного зондування. 3 метою визначення аромату харчових продуктів, створені так звані «електронні носи» (метод, який дозволяє визначати відхилення від регламентованої кольорової гами багатьох забарвлених харчових продуктів, включаючи пакувальні матеріали. Ця методика введена в міжнародний стандарт ISO 9000-9004. Міжнародне агентство з атомної енергії (МАГАТЕ) спільно з Продовольчою і сільськогосподарською організацією Об'єднаних Націй (ФАО) готуються до розробки ручних портативних пристроїв, 3 допомогою яких можна буде швидко та легко виявити підроблені продукти. Спектрометрія іонної рухливості, ядерна технологія, використовувана прикордонною службою при виявленні незаконних наркотиків i вибухових речовин, $є$ одним з декількох методів, які можуть бути адаптовані для проведення точкових тестів для перевірки харчових продуктів на наявність в них сторонніх домішок, забруднення і цвілі. Цей проект об'єднує вчених з 13 країн світу [15].

Слід зазначити, що в Україні $є$ також позитивні зрушення в даному напрямі. Так, вітчизнянняні винахідники створили систему захисту товарів від підробок завдяки унікальному цифровому коду. Підключившись до системи, виробники товарів матимуть можливість маркувати кожну одиницю унікальним цифровим кодом, який містить усю інформацію про походження товару. Система об'єднує ідентифікаційні дані кожної одиниці товару в єдину базу і забезпечує доступність цих даних будь-якому користувачеві, який завантажить на свій гаджет додаток Only Original. Активувавши додаток Only Original на смартфоні, покупець зможе сканувати товари прямо в магазині й миттєво отримувати інформацію, чи $€$ товар оригінальним.Впровадження системи Only 
Original забезпечить виробникові повну прозорість і контроль логістики продукції - від конвеєра до полиці магазину [3].

Проте, незважаючи на вагомі напрацювання у сфері боротьби 3 фальсифікацією і підвищенням якості та безпеки продукції в Україні, які і в світі загалом постають нові проблеми Щорічно зростають масштаби використання харчових добавок. Наприклад, що середній житель Європи щорічно із їжею з'їдає більш як 2,5 кг різних хімічних речовин, які надають харчовим продуктам свіжого вигляду, приємного запаху і продовжують строки їх зберігання [15]..За даних умов особливого значення набуває удосконалення системи нормативів, які забезпечували б здоров'я сучасних людей і наступних поколінь.

Останнім часом інтенсивно розвивається один із сучасних напрямів біотехнології — створення трансгенних продуктів харчування. Свропейське законодавство вимагає при маркуванні вказувати на присутність генетично модифікованих продуктів (вміст модифікованого білка - не більше 2\%) [15]. Проте, проблема експертизи генетично модифікованих продуктів залишається поки що не вирішеною.

Висновки та перспективи подальшого дослідження Боротьба 3 фальсифікацією харчових товарів, повинна здійснюватись у таких нарямах:

- розробка нових та удосконалення існуючих методів експертизи

- створення координаційного центру для збору, аналізу та публікації аналітичних результатів, одержаних окремими центрами та лабораторіями зякості харчових продуктів та продовольчої сировини.

- спільної участі України з Міжнародними організаціями у розробці нових. більш досконалих пристроїв з допомогою яких можна буде швидко та легко виявити фальсифіковані продукти. адаптація законодавства України до вимог законодавства ЄС у сфері регулювання якості харчових продуктів;

- розробка методики оцінки технічної документації, щодо здатності нового обладнання до вироблення якісної і безпечної продукції

- здійснення технологічної експертизи харчових продуктів, тобто оцінка експертом відповідності процесів виробництва, зберігання, транспортування і реалізації харчових продуктів встановленим санітарно-гігієнічним вимогам.

-створення умов для появи конкуренції між приватними та державними лабораторіями та зниження вартості відповідних досліджень.

- обов’язкове підключення виробників харчової продукції до системи Only Original.

\section{Джерела та література}

1. Бондаренко Г. Г. Менеджмент якості і елементи системи управління якістю: навч. посіб. / Г. Г. Бондаренко, М. В. Глєбова, В. П. Сіроклин, Н. В. Чернобай - Харків: Нац. аерокосм. ун-т ім. М. Є. Жуковського «Харк. авіац. ін-т», 2017. - 84 с.

2. Відтепер дослідження харчових продуктів зможуть проводити приватні лабораторії [Електронний pecypc] :- Режим доступу: https://brdo.com.ua/top/vidteper-doslidzhennya-harchovyh-produktiv-zmozhutprovodyty-pryvatni-laboratoriyi/

3. В Україні створили унікальний цифровий код захисту товарів від підробок [Електронний ресурс] :Режим доступу: https://ua.news/ua/v-ukrayini-stvorili-unikalnij-tsifrovij-kod-zahistu-tovariv-vid-pidrobok/

4. Державна служба України з питань безпечності харчових продуктів та захисту споживачів офіційний сайт [Електронний ресурс]: - Режим доступу: http://www.consumer.gov.ua/ContentPages/Pro_Sluzhbu/284/

5. Закон України «Про якість та безпеку харчових продуктів і продовольчої сировини» від 24.10.2002 N 191-IV (Відомості Верховної Ради (ВВР), 2002, N 48, ст. 359) [Електронний ресурс] :- Режим доступу: http:/search.ligazakon.ua/1_doc2.nsf/link1/ed_2004_11_18/Z970771.html

6. Закон України «Про захист прав споживачів» Відомості Верховної Ради УРСР (ВВР), 1991, N 30, ст.379) [Електронний ресурс] :- Режим доступу: https://zakon.rada.gov.ua/laws/show/1023-12/ed20111101

7. Закон України «Про основні принципи та вимоги до безпечності та якості харчових продуктів» (Відомості Верховної Ради України (ВВР), 1998, № 19, ст. 98) [Електронний ресурс] :- Режим доступу https://zakon.rada.gov.ua/laws/show/771/97-\%D0\%B2\%D1\%80 
8. Закон України «Про державний контроль за дотриманням законодавства про харчові продукти, корми, побічні продукти тваринного походження, здоров'я та благополуччя тварин» (Відомості Верховної Ради (ВВР), 2017, № 31, ст.343) [Електронний ресурс] :- Режим доступу: https://zakon.rada.gov.ua/laws/show/2042-19/page

9. Експерт розповів, які сири найчастіше фальсифікуються в Україні [Електронний ресурс] :- Режим доступу: http://milkua.info/uk/post/ak-virobniki-kovbas-osukuut-ukrainciv

10. Исикава Каору. Японские методы управления качеством. - М.: Изд. Экономика, 1988. - 215 с.

11. Капінос Г .І. Управління якістю: навч. посіб. / Г. І. Капінос, І. В. Грабовська. - К. : КондорВидавництво, 2016. - 278 с.

12. Немолочна згущенка: українцям продають отруту замість їжі [Електронний ресурс] :- Режим доступу: http://milkua.info/uk/post/nemolocna-zgusenka-ukraincam-prodaut-otrutu-zamist-izi

13. Осторожно подделка: как украинцев обманывают с товарами [Електронний ресурс] :- Режим доступу: https://politeka.net/news/418936-ostorozhno-poddelka-kak-ukraintsev-obmanyvayut-s-tovarami

14. Панченко М. О. Управління якістю: теорія та практика: навч. посібник / М. О. Панченко. - К. : Центр навч. літ-ри, 2018. - 228 с.

15. Смоляр В. І. Сучасні проблеми ідентифікації та фальсифікації харчових продуктів / В .I. Смоляр[Електронний ресурс] :- Режим доступу: http://medved.kiev.ua/arh nutr/art_2007/n07_2_4.htm

16. Фальсификация продовольственных товаров [Електронний ресурс] :- Режим доступу: https://roscontrol.com /community/ article/ fal-sifikatsiia-prodovol-stviennykh-tovarov/

17. Харрингтон Джеймс. Управление качеством в американских корпорациях. - М.: Экономика, 1990. $272 \mathrm{c}$.

18. Що таке фальсифікація? Наше слово[Електронний ресурс] :- Режим доступу: http://nslovo.com/blog/scho-take-falsyfikatsiya

19. Як виробники ковбас ошукують українців [Електронний ресурс] :- Режим доступу: http://milkua.info/uk/post/ak-virobniki-kovbas-osukuut-ukrainciv

\section{References}

1. Bondarenko G.G., Glebovaб M.V., Syroklin V.P., Chernobayб N.V .( 2017). Menedzhment yakosti i elementy systemy upravlinnia yakistiu [Quality management and elements of the quality management system]. Kharkiv: Nats. aerokosm. un-t im. M. Ye. Zhukovskoho «Khark. aviats. in-t» [ in Ukrainian].

2. Vidteper doslidzhennia kharchovykh produktiv zmozhut provodyty pryvatni laboratorii [From now on, food research can be conducted by private laboratories] (n.d) Retrieved from https://brdo.com.ua/top/vidteperdoslidzhennya-harchovyh-produktiv-zmozhut-provodyty-pryvatni-laboratoriyi/ [ in Ukrainian].

3. V Ukraini stvoryly unikalnyi tsyfrovyi kod zakhystu tovariv vid pidrobok [ Ukraine has created a unique digital code for the protection of goods against counterfeiting] (n.d) Retrieved from https://ua.news/ua/v-ukrayinistvorili-unikalnij-tsifrovij-kod-zahistu-tovariv-vid-pidrobok/[ in Ukrainian].

4. Derzhavna sluzhba Ukrainy z pytan bezpechnosti kharchovykh produktiv ta zakhystu spozhyvachiv ofitsiinyi sait [State Service of Ukraine for Food Safety and Consumer Protection official site] Retrieved from http://www.consumer.gov.ua/ContentPages/Pro_Sluzhbu/284/ [ in Ukrainian].

5. Zakon Ukrainy «Pro yakist ta bezpeku kharchovykh produktiv i prodovolchoi syrovyny» vid 24.10.2002, N 191-IV [Law of Ukraine «On quality and safety of foodstuffs and food raw materials» of 24.10.2002, N 191-IV] (2002). Vidomosti Verkhovnoi Rady (VVR) - Verkhovna Rada (BBR) information Retrieved from http:/search.ligazakon.ua/1_doc2.nsf/link1/ed_2004_11_18/ Z970771.html [in Ukrainian].

6. Zakon Ukrainy «Pro zakhyst prav spozhyvachiv» vid 1991, N 30 [Law of Ukraine «Consumer Protection» of 1991, N 30] (1991). Vidomosti Verkhovnoi Rady URSR (VVR) - Verkhovna Rada USSR (BBR), information Retrieved from https://zakon.rada.gov.ua/laws/show/1023-12/ed20111101[in Ukrainian].

7. Zakon Ukrainy «Pro osnovni pryntsypy ta vymohy do bezpechnosti ta yakosti kharchovykh produktiv» vid 1998, № 19 [Law of Ukraine «On Basic Principles and Requirements for Food Safety and Quality» of 1998, № 19,] (1998). Vidomosti Verkhovnoi Rady (VVR) - Verkhovna Rada (BBR) information Retrieved from https://zakon.rada.gov.ua/laws/show/771/97-\%D0\%B2\%D1\%80 [in Ukrainian].

8. Zakon Ukrainy «Pro derzhavnyi kontrol za dotrymanniam zakonodavstva pro kharchovi produkty, kormy, pobichni pr odukty tvarynnoho pokhodzhennia, zdorovia ta blahopoluchchia tvaryn» vid 2017, № 31 [Law of Ukraine «On State Control of Compliance with Food, Feed, Animal By-Products, Animal Health and Welfare» of 2017, № 31] (2017). Vidomosti Verkhovnoi Rady (VVR) - Verkhovna Rada (BBR) information Retrieved from https://zakon.rada.gov.ua/laws/show/2042-19/page [in Ukrainian].

9. Ekspert rozpoviv, yaki syry naichastishe falsyfikuiutsia v Ukraini [The expert told which cheeses are most often falsified in Ukraine] (n.d) Retrieved from http://milkua.info/uk/post/ak-virobniki-kovbas-osukuut-ukrainciv [in Ukrainian]. 
10. Ysykava Kaoru (1988)Yaponskye metodы upravlenyia kachestvom [Japanese quality management practices]. M.: Yzd. Эkonomyka [in Russian].

11. Kapinos H. I., Hrabovska I. V. (2016). Upravlinnia yakistiu: navch. posib . [Management of Yakistyu: Nav. Posib]. K. : Kondor-Vydavnytstvo [in Ukrainian].

12. Nemolochna zghushchenka: ukraintsiam prodaiut otrutu zamist yizh [Non-dairy condensed milk: Ukrainians are sold poison instead of food] http://milkua.info/uk/post/nemolocna-zgusenka-ukraincam-prodaut-otrutu-zamist-izi [in Ukrainian].

13. Ostorozhno poddelka: kak ukrayntsev obmantvaiut s tovaramy [Careful forgery: how Ukrainians cheat with goods] (n.d) Retrieved from https://politeka.net/news/418936-ostorozhno-poddelka-kak-ukraintsev obmanyvayut-stovarami [in Russian].

14. Panchenko M. O. (2018). Upravlinnia yakistiu: teoriia ta praktyka: navch. posibnyk [Management Yakistyu: theory and practice]. K. : Tsentr navch. lit-ry [in Ukrainian].

15. Smoliar V. I. Suchasni problemy identyfikatsii ta falsyfikatsii kharchovykh produktiv [Nowadays problems and identifiable and counterfeit products] (n.d) Retrieved from http://medved.kiev.ua/arh nutr/art_2007/n07_2_4.htm [in Ukrainian].

16. Falsyfykatsyia prodovolstvennukh tovarov [Falsification of food products] (n.d) Retrieved from https://roscontrol.com /community/ article/ fal-sifikatsiia-prodovol-stviennykh-tovarov/ [in Russian]

17. Harrynhton Dzheims (1990). Upravlenye kachestvom v amerykanskykh korporatsyiakh [Quality Management in American Corporations]. M.: Эkonomyka [in Russian]. .

18. Shcho take falsyfikatsiia? Nashe slovo [What is forgery? Our word] (n.d) Retrieved from http://nslovo.com/blog/scho-take-falsyfikatsiya [in Ukrainian].

19. Iak vyrobnyky kovbas oshukuiut ukraintsiv [As sausage makers deceive Ukrainians] (n.d) Retrieved from http://milkua.info/uk/post/ak-virobniki-kovbas-osukuut-ukrainciv [in Ukrainian].

Стаття надійшла до редакції 18.02.2020 p. 